\title{
Adrenal and gonadal contribution to circulating androgens in spotted hyaenas (Crocuta crocuta) as revealed by LHRH, hCG and ACTH stimulation*
}

\author{
M. Lindeque $\ddagger$ J. D. Skinner and R. P. Millar $\dagger$ \\ * Mammal Research Institute, University of Pretoria, Pretoria 0002, and \\ $\uparrow M R C$ Regulatory Peptides Research Unit, University of Cape Town, Medical School, \\ Observatory 7925, Republic of South Africa
}

\begin{abstract}
Summary. Single venous blood samples were collected from 52 hyaenas and serial samples via indwelling jugular catheters from 8 hyaenas. Social status of the hyaenas was unknown. Radioimmunoassay estimations were specific for testosterone, androstenedione, cortisol and LH. No significant differences could be found between the sexes for concentrations of testosterone (adult $\delta \sigma^{*} 2.9 \pm 1.3 \mathrm{nmol} / \mathrm{l}$; adult 우 (non-pregnant) $1.6 \pm 0.3 \mathrm{nmol} / 1$ ). Androstenedione concentrations in sub-adult males were significantly lower than those in females $(2.3 \pm 0.05$ and $5.5 \pm 1.2 \mathrm{nmol} / \mathrm{l})$. Testosterone and androstenedione concentrations were significantly higher in parous pregnant than in parous non-pregnant females $(4.3 \pm 1.4$ and $1.6 \pm 0.3$; and $23.7 \pm 11.6$ and $6.7 \pm 0.9 \mathrm{nmol} / \mathrm{l}$ respectively). Both LHRH and hCG elicited elevated androgen concentrations in females in different reproductive categories. Androgens are produced by the ovary in the absence of follicular or luteal structures, indicating androgen production by the interstitial tissue of the ovarian stroma.
\end{abstract}

\section{Introduction}

Masculinization of the external genitalia of female spotted hyaenas (Crocuta crocuta) has been attributed to secretion of androgens by the fetal ovary associated with a phase of hypertrophy of interstitial cells in the ovarian medulla (Lindeque \& Skinner, 1982) and in the adult the abundant stromal tissue may be the source of androgen secretion (Matthews, 1939). There are certainly high concentrations of testosterone in the circulation of adult females but these are associated with low concentrations in the ovaries and adrenals, the value in the ovary being lower than that in the testes of males of a comparable age (Racey \& Skinner, 1979). These results may have been affected by episodic fluctuation of hormone production. In an effort to circumvent these difficulties we have repeated some of the experiments and in a small number of animals used a pituitary challenge technique to identify the source of the androgen.

\section{Materials and Methods}

Animals. Spotted hyaenas $(\mathrm{N}=60$ ) from different clans were captured in the Kruger National Park and Umfolozi Game Reserve, Natal, by darting with phencyclidine hydrochloride (Sernylan: Bioceutic Laboratories, St Joseph, MO, U.S.A.). The social status of these animals was unknown. Anaesthesia was maintained in 8 individuals by intravenous administration of a combination of

\footnotetext{
* Reprint requests to: Professor J. D. Skinner.

† Present address: Etosha Ecological Institute, P.O. Okaukuejo, South West Africa/Namibia 9000.
} 
Table 1. Pituitary, gonadal and adrenocortical stimulants used in experimental procedures

\begin{tabular}{|c|c|c|c|c|}
\hline Action & Compound & Preparation & Dosage & Route \\
\hline $\begin{array}{l}\text { Pituitary } \\
\text { stimulant }\end{array}$ & Synthetic LHRH & $\begin{array}{l}\text { Lutal (Hoechst AG, Frankfurt, } \\
\text { West Germany) }\end{array}$ & $0.05 \mathrm{mg}$ & i.v. \\
\hline $\begin{array}{l}\text { Gonadal } \\
\text { stimulant }\end{array}$ & $\begin{array}{l}\text { Chorionic } \\
\text { gonadotrophin }\end{array}$ & $\begin{array}{l}\text { Pregnyl (N.V. Organon, Oss, } \\
\text { The Netherlands) }\end{array}$ & 1500 i.u. & i.m. \& i.v. \\
\hline $\begin{array}{l}\text { Gonadal } \\
\text { stimulant }\end{array}$ & $\begin{array}{l}\text { Chorionic } \\
\text { gonadotrophin }\end{array}$ & $\begin{array}{l}\text { Chorulon (Intervet International B.V., } \\
\text { Boxmeer, The Netherlands) }\end{array}$ & 500 i.u. & i.v. \\
\hline $\begin{array}{l}\text { Adrenal } \\
\text { cortex } \\
\text { stimulant }\end{array}$ & $\begin{array}{l}\text { Corticotrophin } \\
\text { (tetracosactrin) }\end{array}$ & $\begin{array}{l}\text { Synacthen Depot (Ciba-Geigy (Pty) Ltd, } \\
\text { Kempton Park, South Africa) }\end{array}$ & $1 \mathrm{mg}$ & i.m. \\
\hline
\end{tabular}

xylazine hydrochloride $(0.5 \mathrm{mg} / \mathrm{kg})$ (Rompun: Bayer, Leverkussen, West Germany) and ketamine hydrochloride $(5 \mathrm{mg} / \mathrm{kg}$ ) (Ketalar, Parke Davis Laboratories, Cape Town, South Africa).

At the end of the study the animals were exsanguinated after a large intravenous dose of suxamethonium chloride $(2-5 \mathrm{~g} / \mathrm{kg})$. Reproductive status of female hyaenas was determined from observation of the condition of the uterus and morphology of the ovaries. Individuals were allocated to age classes following the technique of Lindeque \& Skinner (1984).

Blood samples. Single venous blood samples were collected from 52 hyaenas and serial samples at 15 -min intervals via indwelling jugular catheters from 8 individuals, for as long as each hyaena remained under general anaesthesia.

All blood samples were collected in heparinized tubes and centrifuged immediately after collection. Plasma was collected and stored at $-20^{\circ} \mathrm{C}$ until assay. After at least three serial samples were collected from individuals under anaesthesia, pituitary, gonadal and adrenocortical stimulants were administered (Table 1).

Radioimmunoassay of steroids. Testosterone determinations were performed on $2.0 \mathrm{ml}$ ether extracts of $0.2 \mathrm{ml}$ plasma using TRK 402 tritiated testosterone (Radiochemical Centre, Amersham, U.K.) and a highly specific antiserum raised against testosterone-3 carboxymethyl-oxime-bovine serum albumin (Millar \& Kewley, 1976). Cross-reaction with all major naturally occurring steroids was $<0.1 \%$ except for dihydrotestosterone for which it was $5.1 \%$. The intra- and interassay coefficients of variation were $3 \cdot 1$ and $8 \cdot 4 \%$ respectively. Sensitivity was $5 \mathrm{nmol} / \mathrm{l}$.

Androstenedione determinations were performed on $2.0 \mathrm{ml}$ hexane-ether $(4: 1, \mathrm{v} / \mathrm{v})$ extracts of $0.2 \mathrm{ml}$ plasma using TRK 454 tritiated androstenedione (Radiochemical Centre, Amersham, U.K.) and an antiserum raised against androstenedione-7 hemisuccinate-bovine serum albumin (Miles Yeda, Kiryat Weizman, Rehovot, Israel). Cross-reaction with all major naturally occurring steroids was $<0.5 \%$. The intra- and interassay coefficients of variation were 3.3 and $6.9 \%$ respectively. Sensitivity was $2 \mathrm{nmol} / 1$.

Cortisol determinations were performed on $2.0 \mathrm{ml}$ ether extracts of $0.2 \mathrm{ml}$ plasma using TRK 609 tritiated cortisol (Radiochemical Centre, Amersham, U.K.) and an antiserum raised against cortisol-21-hemisuccinate-bovine serum albumin. Cross-reaction with all major naturally occurring steroids was $<0.5 \%$. The intra- and interassay coefficients of variation were 3.7 and $23.4 \%$ respectively. Sensitivity was $5 \mathrm{nmol} / 1$ (Carr, Millar \& Crowley, 1977).

Luteinizing hormone $(\mathrm{LH})$ estimations were performed by a double-antibody radioimmunoassay (Millar \& Aehnelt, 1977), using anti-ovine-LH serum No. 15 (kindly donated by G. D. Niswender) and anti-rabbit gamma globulin as second antibody. Purified ovine LH was used for iodination (L. E. Reichert: 1056-C2) and ovine LH (NIH-LH-S18) was used for standards. Sample volume was $0.1 \mathrm{ml}$ plasma. Intra-assay variation was $14.4 \%$ and sensitivity was $0.1 \mathrm{ng} / \mathrm{ml}$. 
Table 2. Mean ( \pm s.e.m.) concentrations of testosterone and androstenedione in male and female spotted hyaenas

\begin{tabular}{|c|c|c|}
\hline & $\begin{array}{l}\text { Testosterone } \\
(\mathrm{nmol} / \mathrm{l})\end{array}$ & $\begin{array}{l}\text { Androstenedione } \\
\text { (nmol/l) }\end{array}$ \\
\hline $\begin{array}{l}\text { Juvenile } \delta \hat{\jmath}(\mathbf{N}=4) \\
\text { Juvenile } ९ \uparrow(N=4)\end{array}$ & $\begin{array}{l}1.2 \pm 0.8 \\
0.9 \pm 0.5\end{array}$ & $\begin{array}{l}2 \cdot 6 \pm 0 \cdot 8 \\
4 \cdot 5 \pm 1 \cdot 2\end{array}$ \\
\hline $\begin{array}{l}\text { Sub-adult } \delta(N=16) \\
\text { Sub-adult }+9(N=11)\end{array}$ & $\begin{array}{l}2.2 \pm 0.6 \\
1.6 \pm 0.5\end{array}$ & $\begin{array}{l}2 \cdot 3 \pm 0 \cdot 5^{*} \\
5 \cdot 5 \pm 1 \cdot 2^{*}\end{array}$ \\
\hline $\begin{array}{l}\text { Adult } \sigma^{\wedge}(N=4) \\
\text { Adult } 90(N=13)\end{array}$ & $\begin{array}{l}2 \cdot 9 \pm 1 \cdot 3 \\
1 \cdot 4 \pm 0 \cdot 3\end{array}$ & $\begin{array}{l}3 \cdot 4 \pm 0.8 \\
5 \cdot 4 \pm 0.9\end{array}$ \\
\hline
\end{tabular}

$* P<0.01$ ( $t$ test $)$.

Table 3. Mean ( \pm s.e.m.) concentrations of testosterone and androstenedione in female spotted hyaenas of different reproductive status

\begin{tabular}{lccc}
\hline & $\begin{array}{c}\text { No. of } \\
\text { females }\end{array}$ & $\begin{array}{c}\text { Testosterone } \\
(\mathrm{nmol} / \mathrm{l})\end{array}$ & $\begin{array}{c}\text { Androstenedione } \\
(\mathrm{nmol} / \mathrm{l})\end{array}$ \\
\hline Nulliparous & 12 & $1 \cdot 1 \pm 0 \cdot 3$ & $4 \cdot 5 \pm 1 \cdot 8$ \\
Parous & 24 & $2 \cdot 5 \pm 0 \cdot 6$ & $11 \cdot 8 \pm 3 \cdot 8$ \\
Nulliparous & 12 & $1 \cdot 1 \pm 0 \cdot 3$ & $4 \cdot 5 \pm 1 \cdot 8$ \\
Parous non-pregnant & 16 & $1 \cdot 6 \pm 0 \cdot 3$ & $6 \cdot 7 \pm 0 \cdot 9$ \\
Parous lactating & 14 & $1 \cdot 5 \pm 0 \cdot 3$ & $6 \cdot 7 \pm 1 \cdot 1$ \\
Parous anoestrous & 2 & $2 \cdot 6(1 \cdot 1-4 \cdot 1)$ & $6 \cdot 1(4 \cdot 6-7 \cdot 6)$ \\
Parous non-pregnant & 16 & $1 \cdot 6 \pm 0 \cdot 3$ & $6 \cdot 7 \pm 0 \cdot 9^{*}$ \\
Parous pregnant & 8 & $4 \cdot 3 \pm 1 \cdot 4$ & $23 \cdot 7 \pm 11 \cdot 6^{*}$ \\
\hline
\end{tabular}

${ }^{*} P<0.001$ ( $t$ test $)$.

\section{Results}

\section{Basal blood samples}

No significant differences could be found between mean concentrations of testosterone and androstenedione in the peripheral circulation of male and female hyaenas (Table 2), except for subadult females which had higher androstenedione concentrations than did sub-adult males. Testosterone values were generally higher in males and androstenedione was generally higher in females. Testosterone and androstenedione concentrations in pregnant hyaenas were significantly higher than in non-pregnant females (Table 3).

\section{Pituitary stimulation}

Figure 1 illustrates the secretory response in LH, androstenedione and testosterone after LHRH administration. In males and females, $\mathrm{LH}$ responded before the androgens. Testosterone in all individuals reached similar concentrations, while androstenedione concentrations varied between individuals of both sexes. 


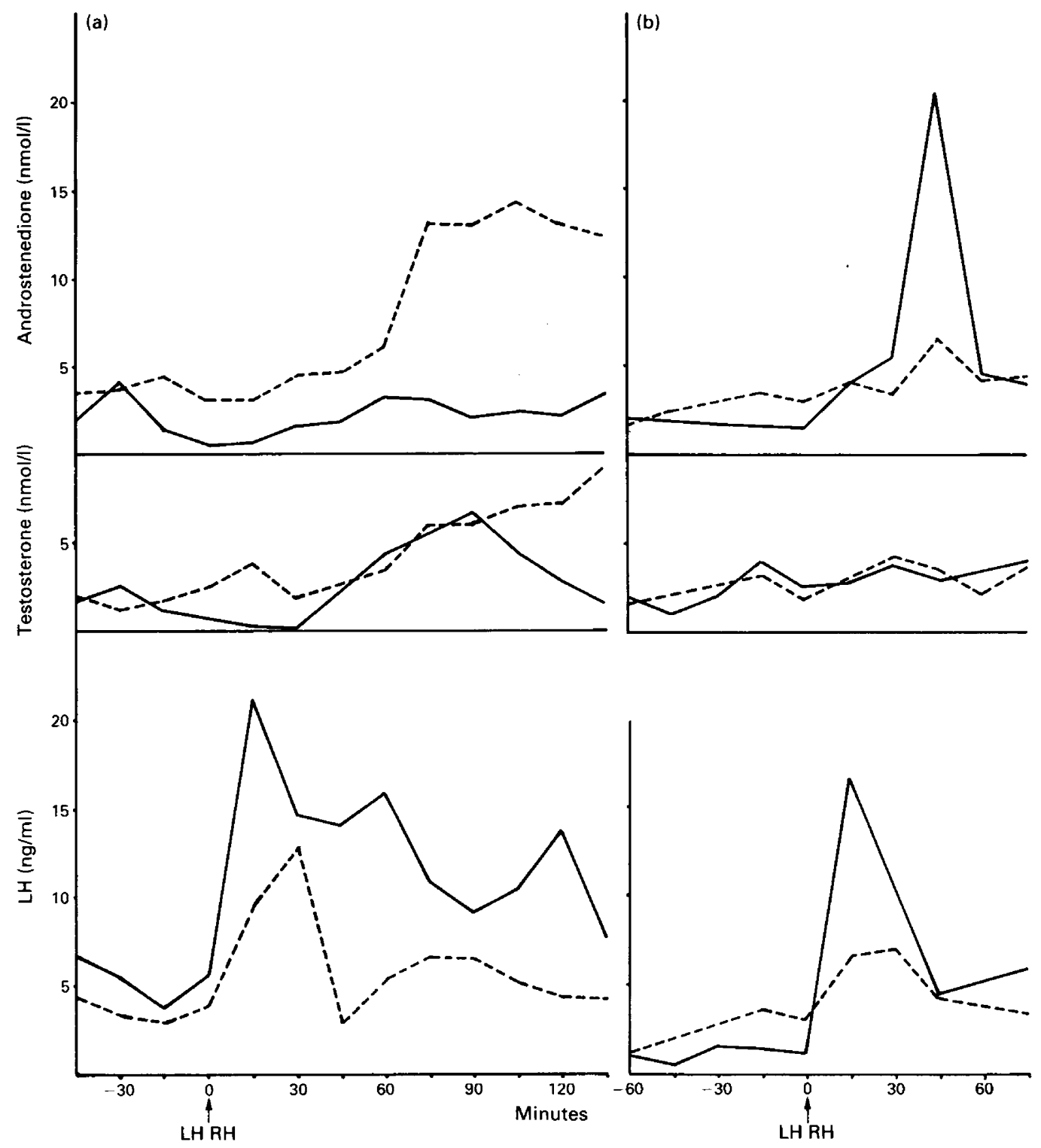

Fig. 1. Peripheral plasma concentrations of $\mathrm{LH}$, testosterone and androstenedione after administration of LHRH to (a) 2 sub-adult males and (b) 1 sub-adult ( $\longrightarrow$ ) and 1 adult anoestrous female (----).

\section{Gonadal stimulation}

Figure 2 illustrates the secretory response of androstenedione and testosterone to hCG in 3 spotted hyaenas. Cortisol levels are included to indicate adrenal secretory activity at the time. In all 3 hyaenas, androgen concentration increased after hCG stimulation. Androstenedione values after hCG stimulation were higher than testosterone in all 3 hyaenas. Both androgens were secreted in higher concentrations in the pregnant female than the other two hyaenas. 


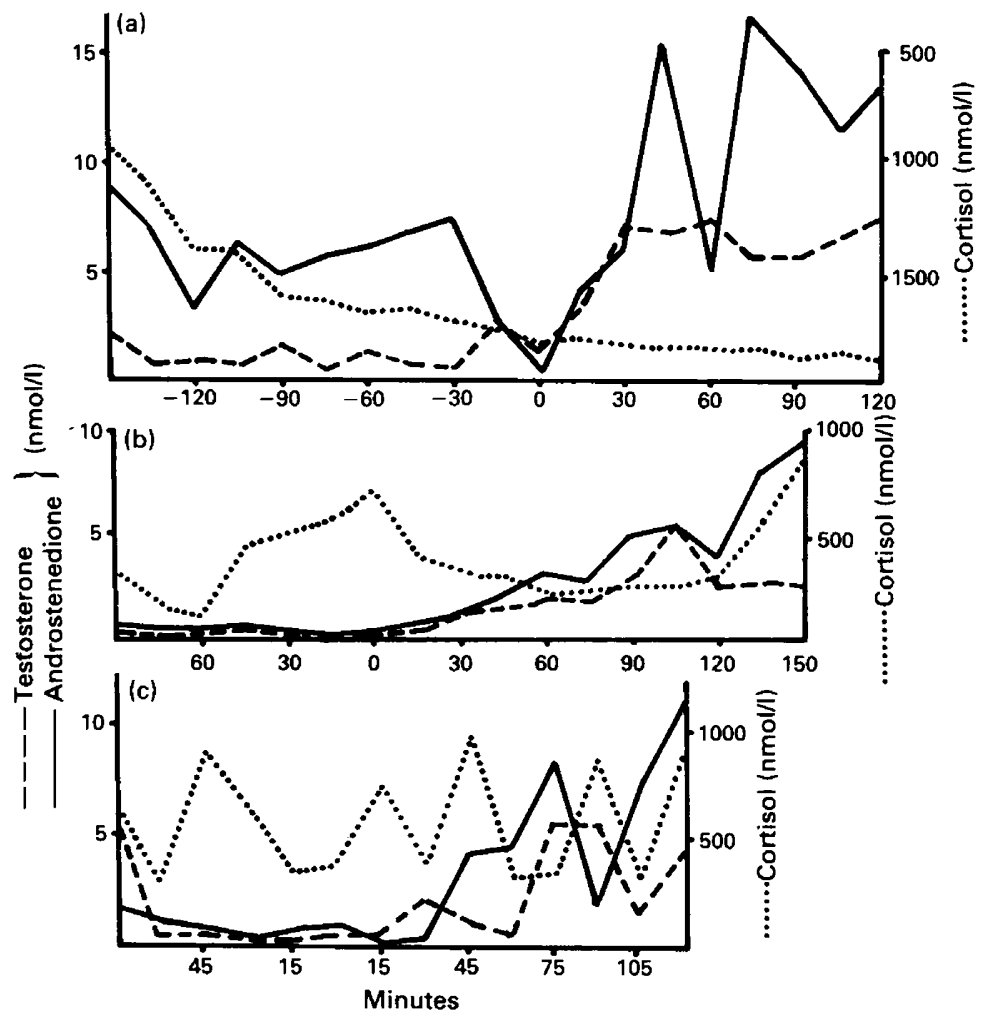

Fig. 2. Peripheral plasma concentrations of cortisol, testosterone and androstenedione after administration of hCG ( $0 \mathrm{~min})$ to (a) an adult pregnant female, (b) an adult anoestrous female and (c) an adult male spotted hyaena.

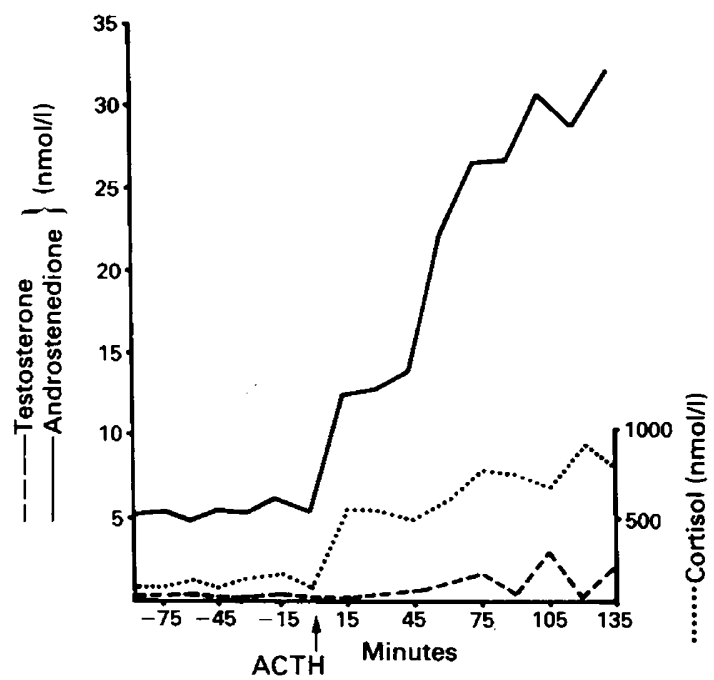

Fig. 3. Peripheral plasma concentrations of cortisol, testosterone and androstenedione after administration of tetracosactrin to a prepubertal female spotted hyaena. 


\section{Adrenocortical stimulation}

Figure 3 illustrates the adrenal secretion of cortisol, androstenedione and testosterone after ACTH administration in a prepubertal female spotted hyaena. Androstenedione was the principal androgen secreted after ACTH stimulation.

\section{Discussion}

Previous indications of similar circulating concentrations of androgens in male and female spotted hyaenas (Racey \& Skinner, 1979) are supported by the present study and it is confirmed that it is impossible to distinguish between the sexes by using the androgen concentrations in a single blood sample. The similarity between androgen values in male and female fetuses (Lindeque \& Skinner, 1982) clearly persists in adults (Table 1). There appears to be an increase in androgen production with age, but males generally have a higher testosterone and females a higher androstenedione concentration. There are also changes in relation to sexual maturation.

Frank, Smith \& Davidson (1985) also found plasma testosterone levels of the same order in 3 male and 2 female spotted hyaenas. Moreover, after gonadectomy, differences remained of the same order, declining by some $25 \%$. Frank et al. (1985) also concluded that testosterone in both sexes was largely of gonadal origin.

It appears that androgens in the female do not fluctuate during the oestrous cycle, as both testosterone and androstenedione remained at similar levels in all non-pregnant females in various phases of follicular development and luteal regression. Significantly higher values for both these during pregnancy are probably due to increased levels of steroid-binding plasma proteins which are characteristic of many pregnant mammals (Gurpide \& Holinka, 1980), although their presence has not yet been shown for hyaenas. In the only other study on circulating testosterone, Gombe (1985) found that concentrations for a pregnant individual and a lactating individual never exceeded $2 \mathrm{ng} / \mathrm{ml}$ over a $22 \mathrm{~h}$ period.

Androgens in blood originate from the direct endocrine gland effluent as well as peripheral conversion of other steroids. Since sampling directly from the venous effluent of the gonads and adrenals was not done we cannot totally rule out peripheral conversion of steroids as a masking influence. However, the time sequence of changes may exclude this possibility. We conclude therefore that androgen concentrations measured after stimulation represent the secretory responses of the particular gland affected.

The rationale for the use of exogenous stimulants of steroidogenic tissues was that individual target endocrine systems could be investigated without the confusion of peripheral steroid interconversion or dual secretion of the same hormone by more than one organ. Prevailing field conditions furthermore dictated the use of a method giving rapid results, and although more individuals are required for statistical interpretation of results, demonstration of secretory activity by the testis, ovary and adrenal was the main objective. From the results it appears that the classical mammalian gonadal-pituitary-adrenal axes of regulation are present in male and female hyaenas. However, androgen concentrations in males were low. Androgens are known to be produced by the adrenals and ovaries of most mammals (Baird, Uno \& Melby, 1969; Eckstein, 1977), but the concentrations produced by the adrenal and ovary of the spotted hyaena are higher than those for most other species. Androstenedione appears to be the principal androgen produced by the testis, ovary and adrenal, although the smaller amounts of testosterone might have a greater biological significance.

Administration of LHRH to males and females evoked similar time courses of responses in $\mathrm{LH}$ and androgens. Both LHRH and hCG caused elevated androgen concentrations in females in different phases of the reproductive cycle and it is unlikely that androgen production is related to the ovarian follicle or corpus luteum. Ovarian production of androgens is therefore attributed to the one ovarian compartment present irrespective of reproductive status; namely the interstitial 
tissue. Lindeque \& Skinner (1982) have previously shown that interstitial tissue occurs in the fetal ovary, in the absence of follicular and luteal tissue.

On the whole, the responses to challenge with LHRH confirmed the validity of interpretations from single samples. Peripheral androgens in the spotted hyaena can be attributed to several origins, of which the adrenal cortex and gonadal interstitium were described in this study. Additional material and more selective trials on individuals in the same reproductive phase are needed to establish the possible role of steroid interconversion in androgen metabolism, and the possible relationship between adrenal and gonadal production of androgens.

We are grateful to the Board of Trustees, National Parks Board of South Africa and Natal Game and Fisheries Preservation Board, for their co-operation in this project. M.L. received scholarships from the CSIR and Transvaal Branch of the Wildlife Society of Southern Africa. R.P.M. is the recipient of grants from the Medical Research Council and the University of Cape Town.

\section{References}

Baird, D.T., Uno, A. \& Melby, J.C. (1969) Adrenal secretion of androgens and oestrogens. J. Endocr. 45, $135-136$.

Carr, P.J., Millar, R.P. \& Crowley, H. (1977) A simple radioimmunoassay for plasma cortisol: comparison with the fluorometric method of determination. Ann. clin. Biochem,14, 207-211.

Eckstein, P. (1977) Endocrine activities of the ovary. In The Ovary, 2nd edn, Vol. 2, pp. 275-313. Eds S. Zuckerman \& B. J. Weir. Academic Press, New York.

Frank, L.G., Smith, E.R. \& Davidson, J.M. (1985) Testicular origin of circulating androgens in spotted hyaena, Crocuta crocuta. J. Zool., Lond. 207, 613-615.

Gombe, S. (1985) Short term fluctuations in progesterone, oestradiol and testosterone in pregnant and nonpregnant hyaena (Crocuta crocuta Erxleben). Afr. J. Ecol. 23, 269271.

Gurpide, E. \& Holinka, C. (1980) Pregnancy-related changes in the metabolism of hormones. In Maternal-Fetal Endocrinology, pp. 45-57. Eds D. Tulchinsky \& K. J. Ryan. W. B. Saunders Co., Philadelphia.
Lindeque, M. \& Skinner, J.D. (1982) Fetal androgens and sexual mimicry in spotted hyaenas (Crocuta crocuta). J. Reprod. Fert. 65, 405-410.

Lindeque, M. \& Skinner, J.D. (1984) Size frequency analysis of tooth wear in spotted hyaenas Crocuta crocuta. S. Afr. J. Zool. 19, 291-294.

Matthews, L.H. (1939) Reproduction in the spotted hyaena, Crocuta crocuta Erxl. Phil. Trans. R. Soc. B 230, 1-78.

Millar, R.P. \& Aehnelt, C. (1977) Application of ovine luteinizing hormone (LH) radioimmunoassay in the quantitating of $\mathrm{LH}$ in different mammalian species. Endocrinology 101, 760-768.

Millar, R.P. \& Kewley, C. (1976) Production of a specific antiserum for testosterone. $S$. Afr. med. J. 50, 1021-1022.

Racey, P.A. \& Skinner, J.D. (1979) Endocrine aspects of sexual mimicry in spotted hyaenas, Crocuta crocuta. J. Zool., Lond. 187, 315-326. 